Combining clauses in interaction. The "voi olla että" '(it) may be that' utterance in Finnish.

\title{
Niemi, Jarkko
}

2015

Niemi , J 2015 , ' Combining clauses in interaction. The "voi olla että" '(it) may be that' utterance in Finnish. ' , Journal of Pragmatics , vol. 77 , pp. 80-96 . https://doi.org/10.1016/j.pragma.2015.01.003

http://hdl.handle.net/10138/156239

https://doi.org/10.1016/j.pragma.2015.01.003

publishedVersion

Downloaded from Helda, University of Helsinki institutional repository.

This is an electronic reprint of the original article.

This reprint may differ from the original in pagination and typographic detail.

Please cite the original version. 


\title{
Combining clauses in interaction. The voi olla että '(it) may be that' utterance in Finnish
}

\author{
Jarkko Niemi * \\ PL 4 (Vuorikatu 3 A), Fl-00014 University of Helsinki, Finland \\ Received 8 June 2014; received in revised form 5 January 2015; accepted 5 January 2015
}

\begin{abstract}
This study focusses on the Finnish utterance type that consists of voi olla '(it) may be' and a span of talk initiated by et(tä) 'that', that follows it. The analysis demonstrates that in an initiating turn, the utterance initiated by the voi olla että '(it) may be that' expresses a lack of knowledge of a state of affairs and usually provides for an expansion on the topic. By contrast, in a responding turn, the displayed lack of knowledge is often related to producing a hedged affirmative answer. Moreover, the study argues that the relative prominence of the two parts of the utterance differ according to its sequential position. In an initiating turn, the talk following voi olla is more prominent. This reflects the function of the turn as initiating something new, which is presented in the talk after et(tä). However, in a responding turn, voi olla gains more prominence than the talk following it, because the stance that voi olla expresses embodies an alignment with the co-participant's prior action. The data used for this study are drawn from audio and videotaped interactions between friends and relatives, as well as customer-service encounters. The methodology for the study is conversation analysis.
\end{abstract}

(c) 2015 Elsevier B.V. All rights reserved.

Keywords: Clause combining; Subordination; Conversation analysis; Finnish

\section{Introduction}

This article analyses the clause combination of voi olla '(it) may be' and a span of talk initiated by et(tä) 'that' during naturally occurring social interaction in Finnish. The first part of this utterance type, the subjectless expression voi olla (lit. 'may be'), offers an epistemic evaluation such that the proposition to be presented in the second, et(tä) 'that'initiated part is possibly true. Example 1 illustrates a usage of this utterance type by a speaker during an evening gathering of four friends. The utterance initiated by the voi olla että '(it) may be that' (henceforth abbreviated as a VOEutterance) is used to respond to a polar question that requests information. One of the speakers, Anna, holds a bowl of sweets in her lap and the sweets are in the shapes of famous politicians' faces. In line 1, another speaker, Tommi, asks for a sweet that is shaped like the face of a specific politician (the transcription and glossing symbols are provided in Appendix A).

\footnotetext{
* Tel.: +358 503185260 .

E-mail address: jarkko.j.niemi@helsinki.fi.
} 
Example 1. Sg123A. A face-to-face conversation.

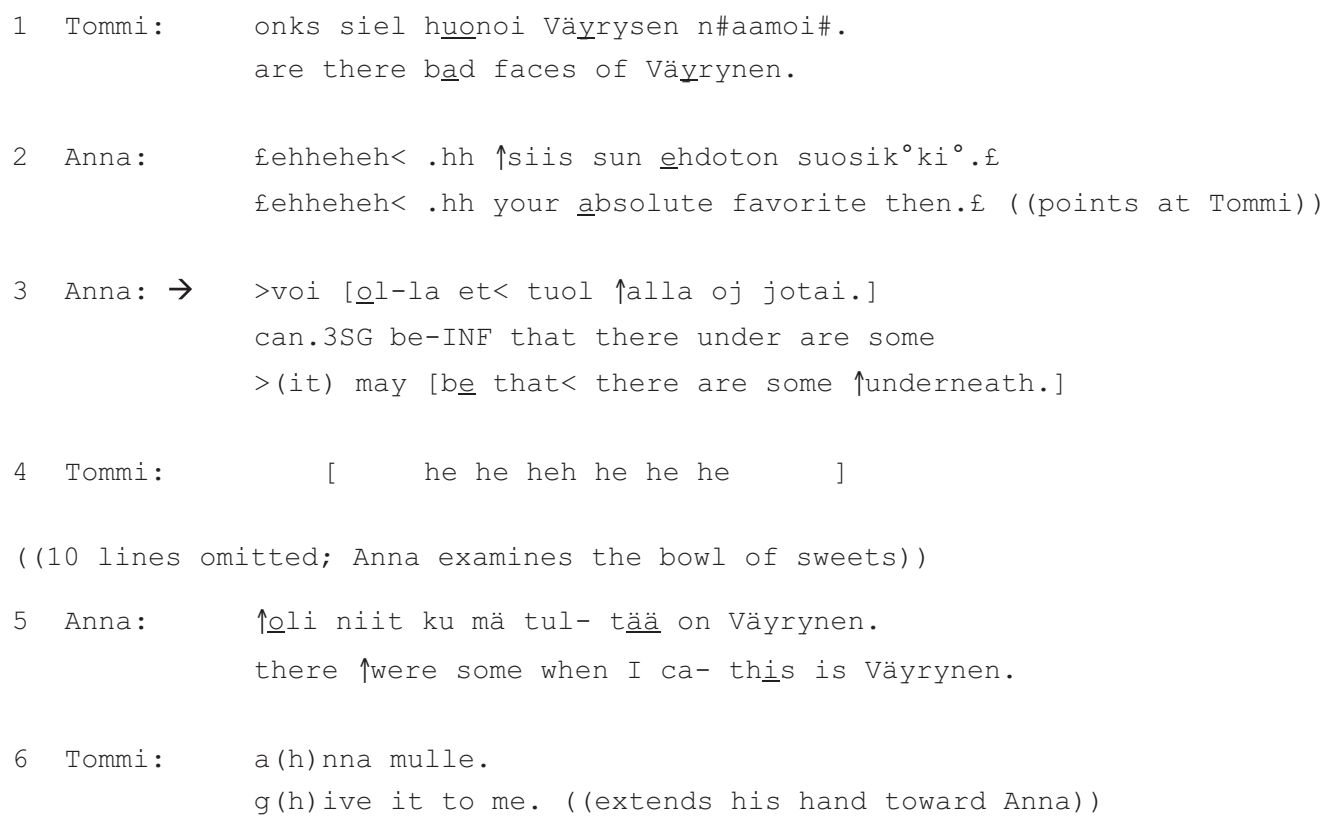

Tommi's request for information (line 1) makes an answer a relevant next action from Anna, but she first laughs and subsequently offers an assessment of the politician as one that is Tommi's favourite (line 2). After this, due to the noncontiguity between the request for information and the answer, answering with a simple 'yes' or 'no' would be less clearly tied to the request for information. For example, a 'no' could be understood as withdrawing from the assessment that Anna just offered. Yet a more elaborate answer, such as a partly repetitive 'there are' or 'there are not', would be possible due to their lexical similarities with the request for information and the tie that is created as a consequence. However, these types of answers would indicate knowledge about the state of affairs. A VOE-utterance (line 3 ) is therefore a useful resource, since voi olla '(it) may be' explicates Anna's uncertainty and the talk that is initiated by et 'that' offers the opportunity to tie the turn to the request for information on line 1 (for example, see the repetition of the polar question's copula verb in tuol alla oj jotai 'there are some underneath' on line 3).

A traditional grammatical description could claim that a VOE-utterance, such as voi olla et tuol alla oj jotai '(it) may be that there are some underneath' (Example 1), consists of a main clause voi olla, '(it) may be', and a subject complement clause that is initiated by et(tä) 'that' (cf. Vilkuna, 2000: 66-67; Hakulinen et al., 2004: §1146). However, it should be noted that as a construction, a VOE-utterance is grammatically rather specialised. For example, there is no parallel expression without the modal verb, *(se) on että '(it) is that' (Hakulinen et al., 2004: §1571). Furthermore, different tenses (e.g. on voinut olla että '(it) may have been that') seem to occur only rarely. Grammatical specialisation aside, what is referred to as the main clause of the VOE-utterance, voi olla '(it) may be', consists of the modal verb voida, 'can; may', in the third-person singular form and the infinitive verb form olla, 'to be'. 1 When the complementizer et(tä) 'that' occurs after the main clause of voi olla, it projects more talk to come (Laury and Seppänen, 2008: 160-164), and the form of this talk is flexible. In other words, the talk after et(tä) may consist of a non-finite phrase, a clause of variable length, or it may be a more extended span of talk. ${ }^{2}$ In a VOE-utterance, voi olla '(it) may be' and the complementizer et(tä) 'that' are produced within the same prosodic unit, and the pitch contour falls only at the end of the talk that is initiated by et(tä) (see Example 1). Finally, it should be noted that in my data, a complement clause that

\footnotetext{
${ }^{1}$ The modal verb voida, like the English verb may, has the epistemic interpretation of 'to be possible' and a deontic interpretation of 'to be allowed', depending on the context of use. In addition, it can have the dynamic interpretation of 'to be able; can' (Hakulinen et al., 2004: §1566). However, when the non-finite verb form olla co-occurs with the verb voida in the third-person singular without an animate subject, it typically expresses an epistemic evaluation that the state of affairs is conceivable or probable, as in voi olla, että tämä ei lopu tähän, '(it) may be that this is not over yet', which was an example offered by a dictionary (Kielitoimiston sanakirja, s.v. voida).

${ }^{2}$ In my data, the speaker always continues after an et(tä) 'that'. Thus voi olla et(tä) '(it) may be that' does not constitute the speaker's turn, as for example the affective utterance niin virkkuna että 'so lively that' may do (Seppänen and Herlin, 2009). On the turn-final particle että in Finnish, see Koivisto, 2012, 2014.
} 
follows voi olla '(it) may be' is invariably initiated by the complementizer et(tä) 'that'. Without et(tä), the voi olla does not necessarily project more talk to come (cf. Niemi, 2013 on the independent clausal response voi olla '(it) may be' and its cognates). In addition, the possible more talk that occurs after a voi olla without an et(tä) does not function as a subject of the evaluation that is presented by voi olla. ${ }^{3}$

Recent studies on the different types of clause combining have discussed the question of whether some parts of a complex sentence have relative prominence as well as the issue of whether what is referred to as the complement clause is in fact subordinate to the main clause or matrix clause (for example, see Hopper and Thompson, 2008; Laury and Suzuki, 2011; Langacker, 2014). A central observation in this research is that the main clause of a complex sentence (such as voi olla '(it) may be' in Example 1) is better understood as a phrase that projects more talk to come and also offers an interpretative frame for it (see Diessel and Tomasello, 2001: 97-98). For example, Thompson (2002) observed that a phrase such as I think in English conveys the speaker's epistemic/evidential stance and frames the upcoming talk. Thompson also proposed that it is the talk following the projector phrase, such as I think, that performs action that is interactionally more relevant. Consequently, that talk is not subordinate to the main clause, or in Thompson's terms, to the complement-taking predicate (CTP). In a similar vein, the study by Günthner (2011) on the German construction die Sache ist, 'the thing is', demonstrated that this CTP projects more talk to come and frames the succeeding talk as the core message (see also Keevallik, 2006 on ei tea 'don't know' initiated questions in Estonian). However, Koivisto et al. (2011) adopt a more cautious position in stating that although topically not the focus of conversation, a CTP such as the Finnish se sano (mulle) että, 'she said (to me) that', is not subsidiary to the upcoming talk. The reason they cite for this is that se sano (mulle) että regulates the participant framework of the conversation by communicating that the current speaker is only the animator of the upcoming talk, while someone else is the author (Goffman, 1981).

Whereas previous studies on the clause combining in interaction have discussed various types of CTPs, they have generally not focused extensively on the sequential position of the bipartite utterance. The present study contributes to current research by exploring the interplay that occurs between the sequential position and the lexico-syntactic and prosodic features of a VOE-utterance in conversation. A central objective of this analysis is to determine whether one part of the VOE-utterance can be identified as being interactionally more prominent, and if so, whether variation occurs in the relative prominence when the VOE-utterance is used in different sequential positions. Furthermore, this study compares the utterances beginning in voi olla että, '(it) may be that', with other epistemic phrases that can project more talk to come (Kärkkäinen, 2003, 2007; Weatherall, 2011), and describes the functional differences between them.

The data for this study are drawn from naturally occurring audio and videotaped interactions between friends and relatives, as well as from customer service encounters (for example, faculty office, health centres, and social insurance offices). ${ }^{4}$ The data consist of approximately $40 \mathrm{~h}$ of conversation, containing 33 instances of utterances initiated by voi olla että, '(it) may be that'.

The analysis of the VOE-utterance is divided into two sections on the basis of the sequential position of the VOEutterance. I will first discuss the use of the VOE-utterance in initiating actions ( 13 examples in the data) and will then turn to examine the use of the VOE-utterance to respond to a first-position turn (20 examples in the data). I will argue that both the initiating and the responding VOE-utterances may be used to assert something that the speaker considers to be possible but not certain, while the function of doing this often varies between the initiating and responding turns. In addition, it will be shown that a VOE-utterance varies in terms of its lexico-syntactic and prosodic design depending on how the utterance is used in an initiating or a responding turn.

\section{VOE-utterance in an initiating action}

In this section, I will analyse the usage of a VOE-utterance in initiating actions: sequence-initiating turns, turns that provide an expansion on the topic, and turns that are part of an extended telling. However, although these usages of the VOE-utterance do not clearly respond to a prior turn, they are in one way or another connected to the prior topic or action line. In Example 2, a VOE-utterance initiates a sequence that is topically disconnected from the prior talk but connects to the embodied conduct of another person. This example is an extract from a conversation involving three friends. In the excerpt below, Miia tells about a practical training period that she is about to begin in the city of Lappeenranta, and Anu has just asked how Miia intends on getting to there.

\footnotetext{
${ }^{3}$ It is interesting to note that the expression '(it) may be' has grammaticalised into a modal particle in, for example, English (maybe) and Estonian (võib-olla), which represents the Finnic family of languages (like Finnish). However, this type of grammaticalisation has not occurred in Finnish (Niemi, 2013: 206).

${ }^{4}$ The data archives are located at the Department of Finnish, Finno-Ugrian and Scandinavian Studies, at the University of Helsinki (examples marked with Sg), and at the Institute for the Languages of Finland (examples marked with T).
} 
Example 2. Sg151A. A face-to-face conversation.

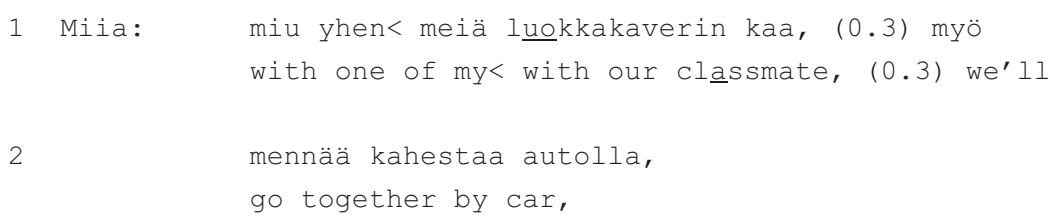

3 Kati: $\rightarrow$ Tnyt Suvi [voi >kuule ol-la et<] siu-n ipää näkkyy=

now 1 NameF can.3sg listen be-INF that you-GEN head show-3sg

个Listen Suvi now [ it) >may be that<] your $\uparrow$ head shows=

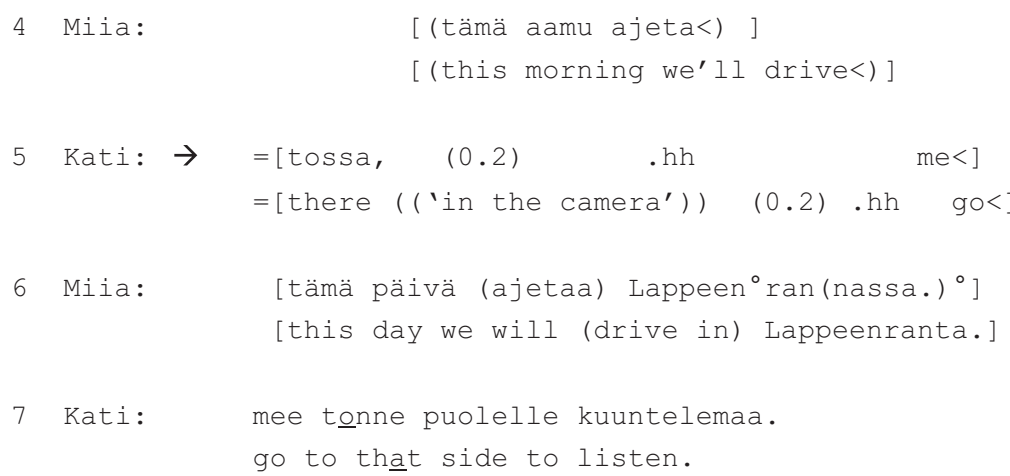

After Miia has answered Anu's question (lines 1-2), Kati uses an utterance that begins with voi olla että '(it) may be' (line 3). ${ }^{5}$ That utterance is addressed to Suvi, although she neither participates in the conversation at that moment, nor is she visible in the recording. The sequence that Kati initiates is topically unconnected to the prior talk between Miia and Anu. Instead, Kati's utterance (line 3 ) initiates a new beginning, ${ }^{6}$ and contains a prosodic and lexical marking that is similar to the one proposed by Couper-Kuhlen (2004: 351-352) for English. In other words, the turn is prefaced by the attentiongetter nyt, 'now', uttered in a high pitch, and a term of address, Suvi, as well as the particle kuule 'listen', which often occurs when the topical line shifts or the on-going activity changes (Hakulinen et al., 2003: 215). The upward rise in pitch, the particles nyt 'now' and kuule 'listen' as well as the address term Suvi all mark the turn on line 3 as being disjunctive from both the earlier sequence and the previous topic, and these features contribute to the interpretation that this utterance advises Suvi to act in a certain way.

The utterance initiated by voi olla että '(it) may be that' (line 3) formulates the proposition siu pää näkkyy tossa 'your head shows there' as a possibility. In this utterance, the CTP voi olla '(it) may be' sets up a scale of probability and frames the following proposition as being somewhere between impossible and certain (cf. Niemi, 2013: 202). This uncertainty results from Kati not actually being able to see Suvi's head in the camera that is recording the situation. Had Kati presented the direct assertion of siun pää näkkyy tossa 'your head shows there', it would have implied that she has direct access to the state of affairs (cf. Stivers, 2005: 133). By using a VOE-utterance, Kati avoids implying direct access and presents the state of affairs as a possibility.

As Example 2 indicates, a VOE-utterance may be used to create a new beginning that is unrelated to the on-going or prior topic. However, this type of usage rarely occurs in the data. Instead, the most frequent usage is one where the VOEutterance continues topically on the prior talk, or in other words, it expands the topic. In Example 3, a VOE-utterance initiates a new sequence that is topically connected to the prior talk. This example is part of an encounter at a hairdresser's shop. The client has been telling about the troubles she has confronted when travelling long distances in a car with her son. In line 1, she continues her telling.

\footnotetext{
${ }^{5}$ As the usage of the particles nyt, 'now', and kuule, 'listen', demonstrates, a VOE-utterance allows for an expansion both before the verbs voi 'may' and olla 'be' and between them.

${ }^{6}$ Kati's turn may of course be interpreted as responding to Suvi's conduct in the room, as was mentioned by an anonymous referee. Nevertheless, my interpretation is that Suvi did not intend that her movement be a social action that would make a response from others as a relevant action.
} 


\section{Example 3. T152b. A face-to-face conversation.}

1 Client: se tosiaan kiljuu se kiljuu niin kovalla äänellä ku he really screams he screams as loud as

se jaksaa autossa ja se on pienessä autossa se on, he can in the car and it is in a little car it is,

3 Hairdr: $\quad\left[{ }^{\circ}\right.$ he he he $\left.{ }^{\circ}\right]$

4 Client: [£kamala] ääni.£

[£a terrible] sound. $£$

5 Hairdr: Joo,

yeah,

6 Client: $\quad\left[{ }^{\circ}\right.$ et $\left.\mathrm{ku},{ }^{\circ}\right]$

$\left[{ }^{\circ}\right.$ so that, ${ }^{\circ}$ ]

7 Hairdr: [.hh on se] a:inahan se on rasittavaa siinä matkan, (.)

[.hh it sure is] it is always stressful there during

8

teossa kun tota:, (.) >siinä on joku tämmönen että

the journey when eh:, (.) >there is something like this

9

niinkun sen< huomaa et juu meil ei nyt 个viihdytä nii

that you notice that yeah we are not $\uparrow$ enjoying this now so

10

se tekee [siitä sem]mosen, (.) tụkalan.

it makes [it kind] of, (.) uncomfortable.

11 Client:

$[$ J으: : : . ]

[yea $:$ h.]

12 Client: on

(it) is.

13

$(1.2)$

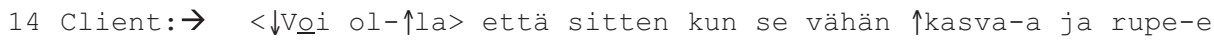
can.3SG be-INF that then when he little grow-3SG and begin-3SG $<\downarrow$ (it) may $\uparrow$ be $>$ that when he grows $\uparrow$ up a bit and begins

15

$\rightarrow \quad$ kuuntele-ej jotain: $\uparrow$ satu-j-a nin, .hh satukaseti-t

listen-INF some fairytale-PL-PAR so fairytaletape-PL

to listen to some $\uparrow$ fairytales so, .hh fairytale tapes 
pieni pelastus on aina välillä tämmönen, (.)

a little salvation once in a while is this kind of,

joku, (.) mm (.) mitä nyt sit soitetaal la stem

some, (.) $\mathrm{mm}$ (.) what we then play to him some kids

In lines 7-10, the hairdresser prepares for the closure of the client's telling by providing an evaluation of it (cf. Stivers, 2013: 201), and the client expresses agreement (line 12) by repeating the copula verb of the hairdressers assessment in line 7, on, 'is' (Hakulinen and Sorjonen, 2009: 127-133). After the silence and the point of a possible sequence closure in line 13 , the client initiates a new sequence but continues to discuss topically what went on previously. ${ }^{7}$ The VOE-utterance offers an assessment (voi olla hyvä, '(it) may be good', line 16; cf. "optimistic projection", Jefferson, 1988) and, by doing this, implies having epistemic access to the state of affairs (Pomerantz 1984a,b: 57; Heritage and Raymond, 2005: 19). Nonetheless, the assessment is hypothetical in the sense that it concerns a future situation, when the child is slightly older. In other words, the CTP voi olla conveys that the speaker has less than direct access to the issue that is being discussed in the upcoming talk just as it did in Example 2. However, in the present example, the VOE-utterance is initiated at the same pitch level as the speaker's prior turn (line 12) ended on. This onset from a relatively low pitch level reflects that this turn does not initiate a new topic, but rather continues topically on what was discussed before (cf. Local, 1992: 280-283). Furthermore, the three highest pitch peaks of the VOE-utterance are located in the talk following että. The first peak occurs at kasvaa 'grows' (line 14), the second at satuja 'fairytales' (line 15), and the third at soimaan 'set to playing' (line 16).

We have thus far examined cases in which the VOE-utterance initiates a sequence of actions. In Example 2, the utterance beginning with voi olla että '(it) may be that' initiated a sequence and a new topic, whereas in Example 3, a VOEutterance provided an expansion on the topic. In both of these usages, the CTP voi olla '(it) may be' functions as an epistemic/evidential phrase (Thompson, 2002) that states a possibility and displays less than certain knowledge about the issue under discussion.

Before moving on to the VOE-utterances in the responsive turns, let us first consider one usage that differs from the previous examples in terms of the sequential organisation of talk. This usage concerns the VOE-utterance within an extended telling. ${ }^{8}$ In an extended telling, participants orient to a suspension of the turn-by-turn talk so that the teller can bring the telling to a completion (Sacks et al., 1974; Mandelbaum, 2013).

As in the prior examples, within an extended telling, the CTP voi olla '(it) may be' of a VOE-utterance functions to display less than certain knowledge about the issue being discussed. However, Example 4 demonstrates that the VOEutterance may also have other functions. In Example 4, which is from an encounter at a health centre, the function of the VOE-utterance is related to more strategic matters, such as dealing with a potentially delicate issue. A nurse is explaining the different options that are available to a pregnant client when she gives birth. In the segment below, the nurse tells about a birthing chair.

Example 4. T143. A face-to-face conversation.

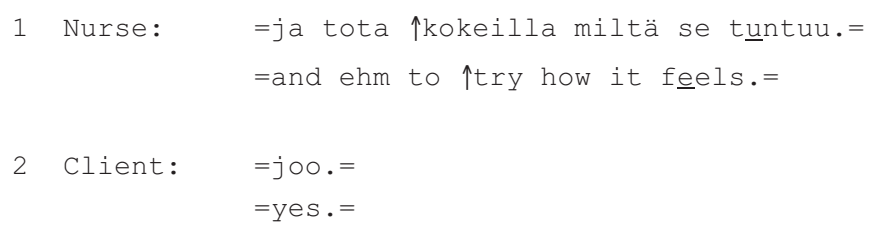

\footnotetext{
${ }^{7}$ Schegloff (2007: 115-168) discusses different types of post-completions after an apparent completion of a sequence. The VOE-utterance in Example 3 could perhaps be analysed as a "post-completion musing" that makes a response only equivocally relevant (Schegloff, 2007: 143).

${ }^{8}$ In Example 3, the client was also engaged in an extended telling, but the VOE-utterance was deployed in a position where this telling was at least momentarily cut off by the haidresser's evaluation.
} 

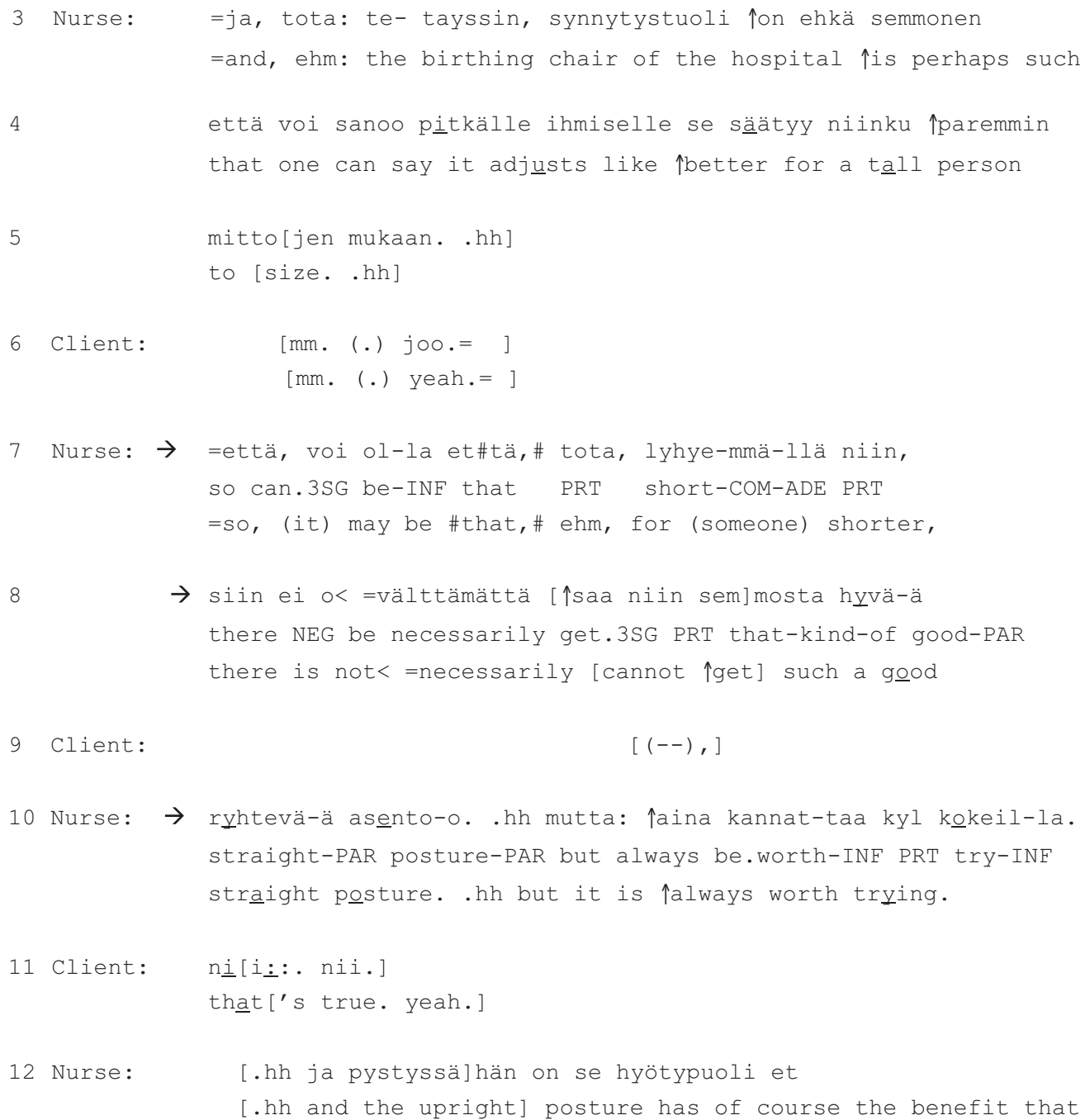

The fact that the VOE-utterance in Example 4 is used as part of an extended telling is manifested by two features. First, the recipient's uptake is minimal. The client does not compete for the floor by making substantive contributions but instead uses minimal response particles that display both her understanding of the telling (lines 2 and 6 ) and her agreement with the nurse's assertion (line 11). Through her responses, the client aligns with the telling and supports the structural asymmetry of the telling in progress (Stivers, 2008: 34). Second, at the points of a possible speaker transition, the nurse uses the turn-initial particles ja 'and' (lines 1, 3 and 12) and että 'so' (line 7) that sustain an orientation to her telling.

In this extended telling, the nurse describes the hospital birthing chair as one that is perhaps best designed for a tall person (lines 3-5). She then uses a turn-initial particle että, 'so', that projects a consequence of the preceding talk to follow (line 7; Koivisto et al., 2011: 86). The following VOE-utterance, uttered in an almost level intonation, formulates the quality of the birthing chair as being uncertain. However, a nurse who explains to her client the different options for giving birth can surely be expected to have knowledge about the hospital birthing chair. This means that rather than reflecting a lack of knowledge, a more probable explanation for the nurse's use of the VOE-utterance is that it might be a sensitive issue to overtly refer to the client as someone who is too short to be able to use the birthing chair. ${ }^{9}$ This sensitivity might also have led the nurse to use the comparative form lyhyemmälle, 'for (someone) shorter' (line 7), by which she generically refers to a third group - short people - and avoids directly characterising the client herself as a short person (for English I think in a similar context, see Kärkkäinen, 2003: 118-119, 157).

\footnotetext{
${ }^{9}$ It is also possible that the nurse has difficulty in estimating the client's height. Nevertheless, the nurse does not formulate her uncertainty as related to the client's height, but as relating to the birthing chair. A further possibility is that the nurse has no access to how another person might experience the birthing chair and expresses epistemic uncertainty for this reason, as was suggested by an anonymous referee.
} 
In this section, a VOE-utterance was used either in a sequence-initiating first-position assertion or within an extended telling. When the VOE-utterance is used in this manner, the CTP voi olla '(it) may be' usually conveys a lack of knowledge that would have otherwise been implied by making a first-position assertion (Examples 2 and 3). This function resembles that of the utterances that are initiated by I don't know in the first-position assessments in English. However, whereas I don't know may be used as an epistemic hedge before an exaggerated complaint or criticism, the VOE-utterance in my data does not exhibit this type of usage (for a sequence-initiating I don't know, see Weatherall, 2011: 326-329). On the other hand, the usage of the VOE-utterance to display a lack of knowledge differentiates it from the English utterances that are initiated by I think (Kärkkäinen, 2003: 122, 128) and I guess (Kärkkäinen, 2007: 190). However, similar to I think, the CTP voi olla may function as a strategic management of the talk by asserting in a sensitive manner something that concerns the recipient (Example 3; Kärkkäinen, 2003: 156-157).

The initiating function of the VOE-utterance is shown in its design in different ways. First, the talk that is initiated by et (tä) 'that' typically (11 cases out of a total of 13 in the data) contains at least one full noun phrase ("that your head shows there", ex. 2; "that when he grows up and begins to listen to some fairytales", ex. 3; and "that for a shorter one there is not necessarily cannot get such a good straight posture", ex. 4). This is one way to indicate that a new line of action or topic has begun. Second, the talk that is initiated by et(tä) may be rather extended and consist of several clauses. This is because the VOE-utterance occurs in the first position and initiates something new, which may require further explanation in order to be understood by the recipient(s). Third, the VOE-utterance is usually not connected to the prior talk by a conjunction (Examples 2 and 3). However, in an extended telling, it is typical for the VOE-utterance to be connected to the prior talk by a connector such as että 'so' (Example 4) or ja 'and', which serve to sustain an orientation to a telling in progress (cf. and I guess in extended turns, Kärkkäinen, 2007: 204-207).

Prosodically, in sequence-initiating VOE-utterances, the talk after et(tä) 'that' is more prominent than the CTP voi olla ' (it) may be'. The utterance reaches its highest pitch peak in the talk following et(tä) 'that'. Example 2 contained a pitch peak in the pronunciation of siun pää 'your head', whereas Example 3 had three peaks, on kasvaa 'grows up', satuja 'fairytales', and soimaan 'to play', and these peaks were all located in the talk following et(tä) 'that'. In Example 4 from an extended telling, a pitch peak occurred on the verb saa 'get' in the talk following et(tä) 'that'. As for the level of loudness, the VOEutterances in this section did not have clear amplitude shifts and they maintained a rather even loudness throughout the complex sentence.

\section{Responding usage of the VOE-utterance}

We now turn to an analysis of the VOE-utterance when it occurs in a conditionally relevant response to a first-position action, such as a request for information by another speaker. In these cases, a VOE-response is typically produced noncontiguously (Sacks, 1987: 59; Benjamin, 2013: 185-215) with the first-position action. In example 1, which is reproduced below, the VOE-utterance responds to a request for information that serves as a pre-request.

Example 1. Sg123A. A face-to-face conversation.Anna's response to the request for information is delayed by her assessment (line 2). At this point, Anna uses the VOE-utterance (line 3) to align with the action line that Tommi pursued, and she proceeds to find a sweet that Tommi asked for. Thus the VOE-utterance offers a provisional answer and it differs from a non-answer response such as I don't know, which the speakers use to not further the activity (Stivers and Robinson, 2006; Keevallik, 2011; Lee, 2013). Finally, Anna locates the requested sweet and provides her final answer by stating, tää on Väyrynen 'this is Väyrynen'.

Whereas the VOE-response was preceded by an assessment in Example 1, a more usual non-answer response preceding a VOE-utterance is a display of a lack of knowledge. In Example 5, a student is in the office that handles Finnish language courses for international students, and the student inquires about the availability of courses on information technology. The VOE-utterance in this example provides the student a provisional answer as well as new information.

Example 5. Sg164 a06. A face-to-face conversation.

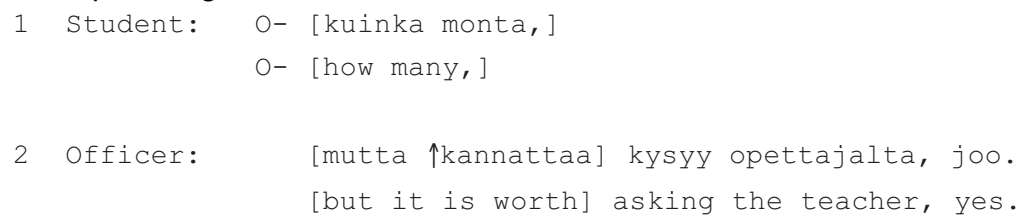


että kuinka \#monta\#.

that how \#many\#.

5 Student: ahaa.

I see.

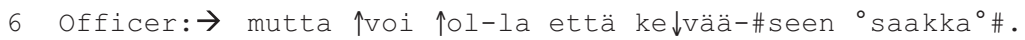

but can.3SG be-INF that spring-ILL until

but (it) 个may ibe that \#until $\downarrow^{\circ}$ spring $^{\circ} \#$.

7 Student: ${ }^{\circ}$ ahaa. ${ }^{\circ}$

${ }^{\circ}$ I see. ${ }^{\circ}$

8 Officer:

>mutta jos sä $\uparrow k a ̈ y t<~ u \underline{u} d e s t a a n$ niin: kysy sitten vielä.

but if you $\uparrow$ come again so: ask again then.

9 Student: [just.]

[okay.]

10 Officer: [mäkin] otan selvää.

[I will] also find out.

11 Student: just eli:kä jos, jos he sanovat, ^miksi et jätit tämä:n

Okay so: if, if they say, 个why didn't you left ${ }^{10}$ thi:s

At the end of line 2, the officer acknowledges the student's question that was posed in overlap with the particle joo 'yes'. Then the officer displays her lack of knowledge by using a complex sentence (lines 3-4). However, this display does not cooperate with the student's question (cf. Pomerantz, 1984b: 610), and as a result, the officer continues by offering her best guess in a turn that she initiates with voi olla että '(it) may be that' (line 6). This VOE-utterance is connected to the prior talk by mutta 'but' which marks a contrastive relationship between the speaker's prior display of lack of knowledge and what she is about to say.

In the VOE-utterance (line 6), the talk initiated by että 'that' provides an answer to the wh-question in line 1 in the form of the postpositional phrase kevääseen saakka, 'until spring' (lit. 'to spring until'). However, the officer goes on to state that she will find whether the information technology courses are available (lines 8 and 10). This means that the answer provided by the VOE-utterance was not the final word on the matter. Furthermore, by first using a non-answer response to state her lack of knowledge (lines 3-4) and by initiating her answer with voi olla että '(it) may be that', the officer demonstrated a problem with the student's assumption that she would have accurate knowledge on the courses (cf. Fox and Thompson, 2010: 143-145). A responding VOE-utterance is therefore used here in a context where a problem in responding is already explicated, and it aligns with the prior display of a lack of knowledge (lines 3-4) by presenting the answer as being uncertain. ${ }^{11}$

In a response to a request for information (Examples 1 and 5), the VOE-utterance provides the recipient a provisional answer and new information. In these answers, the CTP voi olla '(it) may be' functions as an epistemic phrase that displays less than direct access to the matter being discussed. Yet unlike the initiating usage of the VOE-utterance, in responding to a request for information, this display of a lack of knowledge may be a more problematic action to undertake. This is because the speaker who requested the information had assumed that the VOE-speaker possessed the knowledge that s/he was seeking. As a consequence, the answer is typically delayed and it is often preceded by a non-answer response that

\footnotetext{
10 There is a syntactic incongruence between the negative verb form et'didn't' and the affirmative verbjätit'left' during the student's turn in line 11.

11 The same type of function seems to be implemented by the adverb 'probably' in English and Swedish. For example, the adverb antagligen 'probably' in Swedish has a similar function in a similar sequential slot after 'I don't know' in Ja vet inte antagligen tian eller åttnian 'I don't know probably ten or eighty nine' (Keevallik, 2011: 188; see also Beach and Metzger, 1997: 569 on English).
} 
implicates a problem in responding, as shown in Example 5. When the answer is delayed, it may take the form of a VOEutterance, which at the same time conveys a lack of knowledge and offers a possibility to recognisably tie the turn to a firstposition action in the talk initiated by että 'that'.

However, rather than provide new information to the other speaker, a responding VOE-utterance is more frequently used to display a qualified alignment with a first-position turn or to provide a type of response that it was built to prefer (for a recent overview on the organisation of preference in conversation, see Pomerantz and Heritage, 2013; Tainio, 1998 on preference organisation in Finnish). These cases are similar to Examples 1 and 5, where the response offered by the VOE-utterance was delayed, and they indicate a problem in responding (as in Example 5). In Example 6, a VOE-utterance is deployed in response to a polar question that prefers a 'yes'-answer. The context is that Tapani and Mikko and their band were supposed to play at a music festival. However, due to the time conflicts, they have just decided to cancel their gig, and now Tapani is asking Mikko about his plans.

Example 6. Sg141 a04. A telephone call.

1 Tapani: mutta tuu-tsä niinku katt-ele-en sinne ite

but come-2SG.Q PRT watch-FRE-2SG there

but are you like coming there to watch (it) yourself

\#nn\# vai \#n\# ajattel-i-tsä,

or think-PST-2SG.Q

\#nn\# or \#n\# did you think,

3 Mikko: .hh krhm krhm no tota mä en oikeen tiedä kun mm mul

.hh krhm krhm well ehm I don't know for sure because I have

4

- vähä se koko sunnuntai aikataulu \#ee\# epäselvä et

the whole Sunday schedule \#eh\# a bit unclear so

5

se on nii, =

it is so, =

6 Tapani: =joo. (.) joo ju[st joo.]

=yes. (.) yes I [see.]

7 Mikko:

[<silleen $>$ niinku mo[nest as] iast

$[<$ like $>$ ] depending on [many th] ings

8 Tapani:

[no?]

[well?]

9 Mikko: $\rightarrow$ mut tiet'sti (.) tietysti $\uparrow$ voi ol-la et jos siinä

but of course of course can.3SG be-INF that if there

but of course (.) of course (it) ^may be that if there

10

(.) 个jää sitte aika-a et mä, (.) tul-isi-n kat-too ${ }^{\circ}$ mutta. ${ }^{\circ}=$

remain.3SG then time-PAR that 1 SG come-CON-1SG watch-INF but

(.) $\uparrow$ is then time that I, (.) would come watch (it) ${ }^{\circ}$ but. ${ }^{\circ}=$

11 Tapani: =mioo. joo aivan.

=myeah. yeah I see. 
Tapani's polar question in lines 1-2 is not only a request for information, but it also serves as an invitation (the tuutsä 'are you coming' implies that Tapani himself will be present at the event; cf. Drew, 2013: 147). Thus the question displays a preference for a 'yes'-type of answer. Nonetheless, as Mikko does not respond at the first possible point (after ite 'yourself' at line 1), Tapani opens his question to the possibility of a negative response (vai 'or', line 2). ${ }^{12}$ Mikko's answer is also delayed within his turn: it is initiated by an inbreath, coughing, a particle preface (no tota 'well ehm'), and an expression of uncertainty that is followed by an account initiated by kun 'because' (line 3-5). These features mark Mikko's orientation to a preference that was displayed by Tapani's question and they implicate an answer of 'no' (cf. Davidson, 1984: 116). In fact, in line 6 Tapani treats Mikko's response as an answer to his question and he is ready to proceed to a new sequence with a turn that is initiated by no 'well' (line 8).

At this point, Mikko produces an utterance that is initiated by voi olla että '(it) may be that' (line 9). As in Example 5, this utterance is connected to the prior talk by the connector mut, 'but', which marks a contrastive relationship between what Mikko first said and what he is about to say next. In addition, the onset of the VOE-utterance has a high pitch with an upward shift in amplitude, which also serves to imply a distinction from what was said before (see Goldberg, 1978 on amplitude shifts in English conversation). After the CTP voi olla '(it) may be', the first et 'that' is followed by a jos 'if' clause that states the conditions for Mikko attending the festival. The clause after the second et 'that' reproduces with a slight modification the words that Tapani used in his question: tuutsä 'are you coming' (line 1) $\rightarrow$ tulisin 'I would come' and katteleen 'to watch' (line 1) $\rightarrow$ kattoo 'to watch'. ${ }^{13}$ Consequently, by the second et 'that' - clause after the CTP voi olla '(it) may be', Mikko provides a preferred 'yes' type of answer to the question on line 1. However, he ends his turn with the particle mutta, 'but', which implies that the conditions stated earlier (the if-clause) and reservations (the lack of certain knowledge) still hold (Koivisto, 2012), and that Mikko's attendance at the festival is uncertain.

Finally, let us consider in more detail the characteristics of a VOE-response. Example 7 is an extract from a class on Finnish as a second language. In the excerpt below, the teacher is using an overhead projector to show a transparency that has pictures that depict a fictional character, Pekka, in different everyday situations. The students are instructed to narrate what happens in the pictures and the pedagogical focus is on the case marking of the object in Finnish. ${ }^{14}$

Example 7. Sg372. A face-to-face conversation.

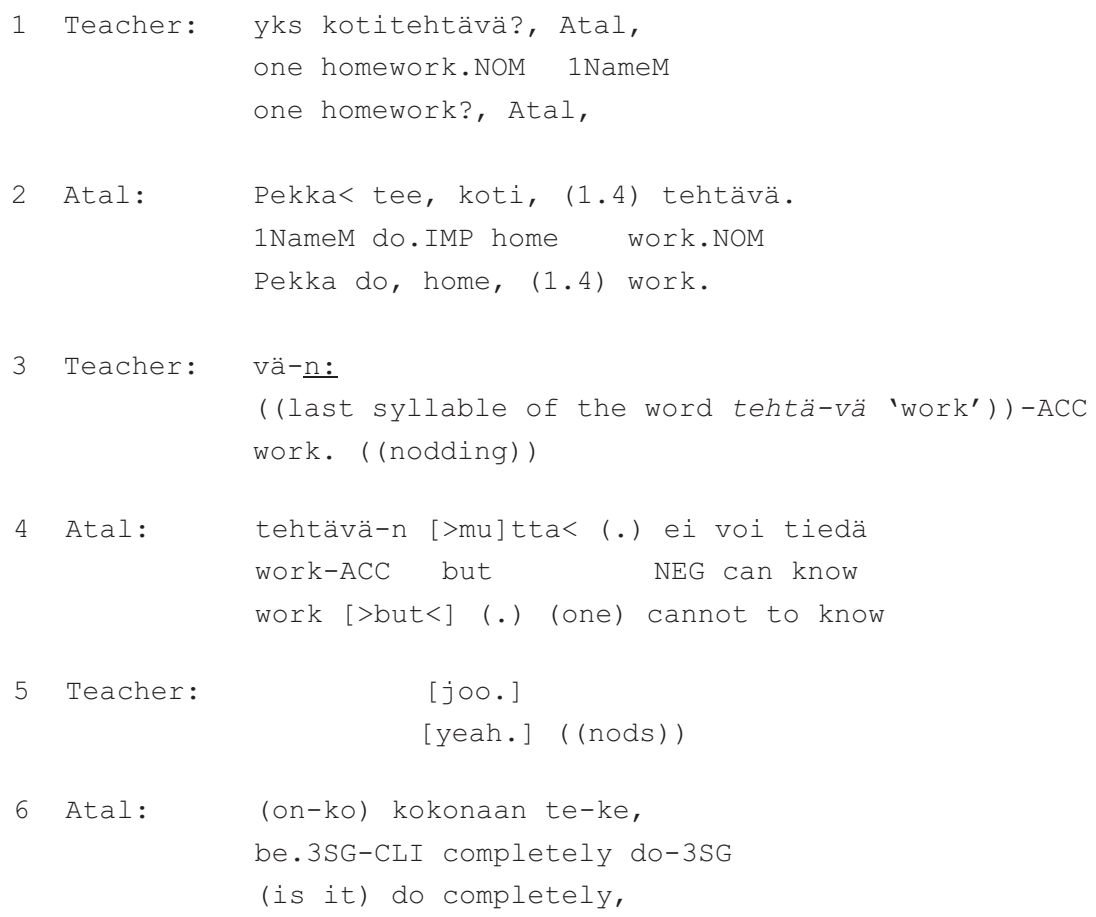

\footnotetext{
${ }^{12}$ The conjunction vai 'or' is used in interrogatives to present mutually exclusive alternatives of which one should be selected.

${ }_{13}$ Mikko (line 10) modifies the verb katteleen 'to watch' that is used by Tapani on line 1 by omitting the frequentative affix from it. The frequentative form mediates affective interpretation, which relates to the convivial nature of Mikko attending the event (Hakulinen et al., 2004: §1735).

${ }^{14}$ The object of incomplete processes in Finnish active sentences is marked with the partitive case (Katsoin elokuva-a, lit. I watched a moviePAR, 'I was watching a movie [but did not finish it]'), whereas the object of completed processes is marked with the accusative case (Katsoin elokuva-n, lit. I watched a movie-ACC, 'I watched a movie [completely]').
} 
7

Teacher: oke:i,

oka:y,

8

9 Atal:

Ate

$$
\begin{aligned}
& {[j \circ(h) \circ \text { ho ho] }} \\
& \text { [yeah he he he] }
\end{aligned}
$$

[sitten h]än te-kee kotitehtä vä̈[-ä nyt]

then he do-3SG homework-PAR now

[in that case] he is doing his home[work now]

10 Teacher:
tä-ssä (.) kuva-ssa, =
this-INE picture-INE
in this (.) picture, =

11 Atal: =joo,

=yes,

12 Teacher:
.h no sitte Samuel sano-i jo e[ttä illa-lla, ]
PRT then 1NameM say-PST already that evening-ADE
. $h$ well then samuel already said [that in the evening,]

13 Atal:

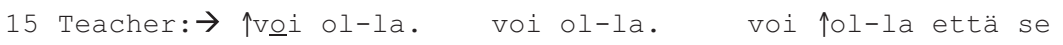
can.3SG be-INF can.3SG be-INF can.3SG be-INF that it 个may be. may be. (it) may $\uparrow$ be that it

17 Atal: joo,

yes,

18 Teacher: jhoo

-yes

20 Teacher: no sitten kun Pekka o-n teh-nyt kaikki kotitehtävä-t?, PRT then when 1 NameM be-3SG do-PPC all homework-PL well then when Pekka has done all his homework?, 
In line 3, the teacher completes a three-part sequence of an initiation-reply-evaluation that is typical of classroom interaction (Mehan, 1985; Ruuskanen, 2007). She corrects the case marking of the object kotitehtävä 'homework' in Atal's answer (line 2) from the nominative case to the accusative case. ${ }^{15}$ After Atal and the teacher have discussed that Pekka might not finish his homework, as the accusative case of the object implies (lines 4-11), the teacher is ready to move on to the next picture on the transparency (line 12). Nevertheless, Atal deploys an initiating VOE-utterance (lines 13-14) as an expansion on the topic and proposes a plausible reason for Pekka not completing his homework.

This VOE-utterance resembles Example 3 (fairytaletapes). Atal uses it after an apparent sequence closure to continue the topic of the prior talk and to indicate less than certain knowledge about the matter being discussed. In addition, this VOE-utterance initiates a new sequence by making relevant a second evaluation from the teacher and it displays a preference for agreement. The teacher then offers her evaluation and asserts unconditional agreement (cf. Hakulinen and Sorjonen, 2009: 127-133) with Atal's proposal. She does this by repeating twice, in separate prosodic units, the voi olla " (it) may be' evaluation of Atal's turn. The teacher then uses a VOE-utterance. While this utterance also responds to Atal's proposal and aligns with it, it differs from the freestanding response of voi olla by formulating a proposition in the talk that follows että 'that'. Due to this proposition, a VOE-utterance is syntactically more independent from the first-position assertion than a freestanding response of voi olla '(it) may be'. As a more independent action, the VOE-utterance also shares characteristics of a first-position action, and due to the että 'that' - initiated talk that formulates recognisably the same idea that was presented in the first-position assertion (see lines 14 and 15-16), it claims a higher commitment to the first-position assertion than a freestanding voi olla '(it) may be' utterance. ${ }^{16}$ Thus, combining a stretch of talk that is initiated by että 'that' with an epistemic evaluation can be one means of reducing the responsiveness of a second-position turn (cf. Heritage and Raymond, 2005: 22-30). Additionally, the talk initiated by että 'that' makes it possible to modify the firstposition assertion. For this reason, this clause combination is a useful resource in contexts such as those involving teacher-student interactions. In this particular example, the teacher states that Pekka's homework may not get done completely and thus uses the VOE-utterance to offer a more straightforward reason for the usage of the partitive case ending on the object kotitehtävä-ä, homework-PAR (line 8).

Example 6 provides us a possibility to compare an initiating VOE-utterance and a responding VOE-utterance because it contains both of the two types of utterances. In this case, the greatest difference is in the prosodic realisation of the VOEutterance. In the initiating VOE-utterance (lines 13-14), the pitch and loudness of the CTP voi olla '(it) may be' and the talk following että 'that' are evenly prominent, which is the most frequent occurrence in my data (cf. Examples 2-4). By comparison, in the responding usage (lines 15-16), the CTP voi olla is more prominent, which again is something that frequently occurs in the data (cf. Examples 5 and 6). As a sign of the relative prominence of the CTP voi olla, there is a high pitch peak when pronouncing the verb 个olla 'to be' (marked by an upward arrow, line 15) and it is louder than the talk following että. ${ }^{17}$ These prosodic differences reflect the functional difference between a VOE-utterance that initiates something new (when the talk after että 'that' is more prominent) and one that provides a provisionally aligning response to a first-position action (the CTP voi olla '(it) may be' is more prominent). ${ }^{18}$

In this section, we have observed that a responding VOE-utterance can be used to offer a provisional answer and new information to the recipient, and it also can be used to align with a preference displayed by a first-position turn. In most cases, the VOE-response is not produced contiguously with a first-position turn, but rather, it is preceded by a non-answer response, which is often an account such as an expression of a lack of certain knowledge. Hence, a responding VOEutterance is often used when a simple response is not possible and some extra interactional work is required.

In terms of the grammatical design of the responding VOE-utterance, in most cases (12 out of a total of 20), a full noun phrase that was used in the first-position turn is protermed in the talk that is initiated by että 'that'. Moreover, the span of talk that is initiated by että is usually considerably shorter than on the initiating utterances (voi olla et se jää kesken, '(it)

\footnotetext{
15 The teacher states her correction by only producing the last syllable, vän, of the word kotitehtävä-n, 'homework'-ACC.

${ }^{16}$ It should also be noted that the VOE-utterance in example 6 occurs in a sequential position where a response to a first-position action is less relevant, because a response is already offered by the voi olla utterances. In other words, this VOE-utterance is sequentially more loosely connected to the first-position action than the voi olla utterances.

17 Similar to example 4 (fairytaletapes), the initiating voi olla että utterance in (6) is produced with a slightly rising pitch in the CTP voi olla että '(it) may be', and in the että initiated talk, there are two prosodic units produced with an almost identical, falling pitch contour: hän ei ymmärrä 'he doesn't understand' and kokonaan 'completely'. The onset of these units is from approximately the same level as the highest pitch point in the CTP voi olla että. Regarding the loudness of the initiating voi olla että utterance, the beginning of the utterance is louder due to the overlapping talk in lines 12-13 (cf. Goldberg, 1978: 199), but otherwise the utterance is produced with even loudness. On the contrary, in the responding utterance of voi olla että, there is a pitch peak in producing the verb olla 'to be' in the CTP voi olla, while the että-initiated talk is initiated lower and produced with a falling intonation and with a creaky voice at the end. The loudest part of the responding voi olla että utterance is in the CTP voi olla että, whereas the talk following että is uttered quietly and with a creaky voice at the end.

${ }^{18}$ However, an exception to this generalisation occurs in the context of overlapping talk (Example 1). The overlapping talk may force the speakers to stress their talk more even in the latter part of their responsive turn.
} 
may be that it remains unfinished', Example 7, and voi olla että kevääseen saakka '(it) may be that until spring', Example 5), and the että-initiated talk in a VOE-response often repeats the predicate of the first-position turn (as in Example 6: tuutsä niinku katteleen sinne 'are you like coming to watch it' $\rightarrow$ et mä tulisin kattoo 'that I would come to watch it'; cf. news interview responses initiated by a stance marker such as I wouldn't argue and a complement clause that recycles linguistic elements from the interviewer's turn, Haddington, 2007). These common features convey that the VOE-response offers a qualified agreement or alignment with a prior first-position turn.

A responding VOE-utterance resembles a response that is initiated by I guess in English in that both of them align with the first-position action. However, in contrast to I guess, the VOE-response does not implicate that in response to some evidence in a prior turn, a change in the speaker's state of knowledge has occurred (see Kärkkäinen, 2007: 203 on responses initiated by I guess). Yet both the VOE-response and the I guess initiated response differ from the utterances that are initiated by I think, which do not align with the first-position action, but introduce a different slant or perspective to the issue at hand (Kärkkäinen, 2003: 130-132; for the Finnish mun mielestä 'In my opinion; I think', see Rauniomaa, 2007: 228-233). Finally, a VOE-response is used in a different sequential slot than 'I don't know' and other similar non-answers. This becomes apparent in Examples 5 and 6, where 'I don't know' occurs before the VOE-response. In English, the same type of sequential difference appears to occur between I don't know and probably. For example, I don't know is used in a responding turn before offering a best guess by through work or Kay probably (Beach and Metzger, 1997: 569; see also Keevallik, 2011: 188).

\section{Discussion and concluding remarks}

This study has demonstrated that an utterance initiated by voi olla että '(it) may be that' can be used to both initiate a first-position turn and to respond in a second-position turn. In both these sequential positions, the VOE-utterance is connected to the prior topic or prior line of action (verbal or embodied, as in Example 2), and it displays either less than direct access to the state of affairs or a lack of certain knowledge. In an initiating turn, this display is most often used for expanding the topic, whereas in a responding turn, it marks an answer to the prior first-position turn as provisional or aligns with a preference displayed by that first-position turn. Overall, the VOE-utterance is a resource for speakers in discussing something that is related to either a prior topic or an action line and in asserting something that they consider to be possible but not certain.

We have seen that the initiating usage of a VOE-utterance differs from the responding usage both lexico-grammatically and prosodically. These differences reflect the function of the VOE-utterance in initiating something new that needs to be explained or offering a qualified agreement or alignment with a prior first-position action. In consequence, the discussion on the relative prominence of what is called the main clause and the complement clause needs to take into account the sequential context of the complex clause. The two parts of a bipartite utterance may differ in both their functional and their prosodic prominence in terms of their sequential position.

The study has also demonstrated that the clause combination of voi olla '(it) may be' and the talk initiated by et(tä) 'that' is often delayed from the prior talk that it connects to. For example, the VOE-utterance is a resource for giving a noncontiguous answer (see Examples 1, 5 and 6). In addition, it may be used to provide a topic expansion when the sequence had already reached an apparent closure (Examples 3 and 7 ). As a consequence, the grammatically elaborated structure of the VOE-utterance may be seen as an adaptation to a sequential position that calls for extra interactional work.

Finally, it should be noted that whereas the current study has dealt with the subjectless CTP voi olla ('may be'), there is a similar CTP that contains the expletive subject se 'it' before the verb (se voi olla että 'it may be that', cf. Laury, 2012: 505-506; Siro, 1968). Relevant in this connection is a study by Niemi (2013) on a group of free-standing response types that include voi olla 'may be' and se voi olla 'it may be'. Niemi shows that there is a difference between these two response types. The subjectless response (voi olla, 'may be') claims independent and at least equal epistemic access to the matter being discussed, whereas the same type of response with an expletive subject (se voi olla, 'it may be') conveys an epistemic stance that the speaker is less knowledgeable than the prior speaker, or that the speaker's perspective on the matter being discussed differs from that of the prior speaker. While this distinction also seems to be relevant for the utterances that begin with voi olla että, 'may be that' (without the expletive subject), and se voi olla että, 'it may be that' (with the expletive subject), ${ }^{19}$ a further study should be conducted on the functional differences between these two utterance types.

This study has lent support to the view that analysing naturally occurring interaction may lead us to rethink a priori linguistic categories such as main clause and subordinate clause. On the other hand, the study of social interaction gains from the study of grammatical constructions the observation that linguistic units are not only fitted to a particular sequential

\footnotetext{
${ }^{19}$ For example, an utterance that is initiated by se voi olla että, 'it may be that', can be employed in a position where the speaker states something that is within the recipient's epistemic domain (Stivers and Rossano, 2010: 8-9, Heritage, 2012a: 4-6, Heritage, 2012b: 32-33) such as se voi olla että se on sulle tyypillistä, 'it may be that it is typical of you'.
} 
environment, but a conventional grammatical construction, or a social action format (Fox, 2007), may be put into operation in different sequential positions to accomplish similar types of actions.

\section{Acknowledgements}

I would like to thank Markku Haakana, Tiina Onikki-Rantajääskö, Marja Leena-Sorjonen, and the anonymous reviewers for their valuable comments on this paper, as well as my colleagues at the Finnish Centre of Excellence in Intersubjectivity in Interaction, which is funded by the Academy of Finland and the University of Helsinki, for the discussions on different occasions.

\section{Appendix A}

Transcription symbols

$. / / /, / ?, / ? \quad$ falling/slightly falling/level/slightly rising/rising intonation

$\uparrow / \downarrow \quad$ pitch upstep/downstep at the start of the following syllable

tonne emphasis indicated by underlining

: lengthening of a sound

[] overlapping talk

(.) micropause, less than $0.2 \mathrm{~s}$

(0.5) silences timed in tenths of a second

$>\quad$ talk inside is at a faster pace than the surrounding talk

$<>\quad$ talk inside is at a slower pace than the surrounding talk

en $<\quad$ glottal stop

a- cut off

$=\quad$ latching of turns

(joo) uncertain hearing

£joo£ smiling voice

\#joo\# creaky voice

${ }^{\circ} \mathrm{joo}^{\circ}$ talk inside is more quiet than the surrounding talk

.hh audible inhalation

(h) exhalation or laughter within a word

(---) unclear talk, not heard by transcriber

(()) comment by a transcriptionist

Glossing symbols

ACC accusative (object)

ADE adessive ('at', 'on')

CLI clitic particle

COM comparative

CON conditional

FRE frequentative

GEN genitive (possession)

ILL illative ('into')

IMP imperative

INE inessive ('in')

INF infinitive

NOM nominative

NEG negation

PAR partitive (partitiveness)

PPC past participle

$P L \quad$ plural

PRT particle

PST past tense

$Q \quad$ Interrogative

SG singular

1 nameF first name, female

1 nameM first name, male 


\section{References}

Beach, Wayne A., Metzger, Terri R., 1997. Claiming insufficient knowledge. Hum. Commun. Res. 23, 562-588.

Benjamin, Trevor, 2013. Signaling Trouble: On the Linguistic Design of Other-Initiation of Repair in English Conversation (Grodil Dissertations in Linguistics 121). University of Groningen, Groningen.

Couper-Kuhlen, Elizabeth, 2004. Prosody and sequence organization in English conversation: the case of new beginnings. In: Couper-Kuhlen, Elizabeth, Ford, Cecilia E. (Eds.), Sound Patterns in Interaction. Cross-Linguistic Studies from Conversation. Typological Studies in Language, vol. 62. John Benjamins, Amsterdam, pp. 335-376.

Davidson, Judy, 1984. Subsequent versions of invitations, offers, requests, and proposals dealing with potential or actual rejection. In: Atkinson, J. Maxwell, Heritage, John (Eds.), Structures of Social Action. Studies in Conversation Analysis. Studies in Emotion \& Social interaction. Cambridge University Press, Cambridge, pp. 102-128.

Diessel, Holger, Tomasello, Michael, 2001. The acquisition of finite complement clauses in English: a corpus-based analysis. Cogn. Linguist. 12, 97-141.

Drew, Paul, 2013. Turn design. In: Sidnell, Jack, Stivers, Tanya (Eds.), The Handbook of Conversation Analysis. Wiley-Blackwell, Chichester, pp. 131-149.

Fox, Barbara, 2007. Principles shaping grammatical practices: an exploration. Discourse Stud. 9, 299-318.

Fox, Barbara, Thompson, Sandra A., 2010. Responses to Wh-questions in English Conversation. Res. Lang. Social Interact. 43, $133-156$.

Goffman, Erving, 1981. Forms of Talk. Basil Blackwell, Oxford.

Goldberg, Jo Ann, 1978. Amplitude shift. A mechanism for the affiliation of utterances in conversational interaction. In: Schenkein, Jim (Ed.), Studies in the Organization of Conversational Interaction. Language, Thought, and Culture. Advances in the Study of Cognition. Academic Press, New York, pp. 199-218.

Günthner, Susanne, 2011. N be that-constructions in everyday German conversation: a reanalysis of 'die Sache ist/das Ding ist' ('the thing is')clauses as projector phrases. In: Laury, Ritva, Suzuki, Ryoko (Eds.), Subordination in Conversation. A cross-Linguistic Perspective. Studies in Language and Social Interaction, vol. 24. John Benjamins, Amsterdam, pp. 11-36.

Haddington, Pentti, 2007. Positioning and alignment as activities of stancetaking in news interviews. In: Robert, Englebretson (Ed.), Stancetaking in Discourse. Pragmatics \& Beyond New Series 164. John Benjamins, Amsterdam, pp. 283-317.

Hakulinen, Auli, Sorjonen, Marja-Leena, 2009. Designing utterances for action: Verb repeat responses to assessments. In: Haakana, Markku, Laakso, Minna, Lindström, Jan (Eds.), Talk in Interaction. Comparative Dimensions. Studia Fennica Linguistica 14. Finnish Literature Society, Helsinki, pp. 124-151.

Hakulinen, Auli, Keevallik Eriksson, Leelo, Lindström, Jan, 2003. Kuule, kule, hördu-projicerande praktiker i finska, estniska och svenska samtal (Kuule, kule, hördu-projecting practices in Finnish, Estonian and Swedish conversation). In: Nordberg, Bengt, Keevallik Eriksson, Leelo, Kerstin, Thelander, Mats, Thelander (Eds.), Grammatik och samtal. Studies till minne av Mats Eriksson. Institution för Nordiska språk vid Uppsala Universitet, Uppsala, pp. 199-218.

Hakulinen, Auli, Vilkuna, Maria, Korhonen, Riitta, Koivisto, Vesa, Heinonen, Tarja Riitta, Alho, Irja, 2004. Iso suomen kielioppi (A Comprehensive Finnish Grammar). Suomalaisen Kirjallisuuden Seura, Helsinki.

Heritage, John, 2012a. Epistemics in action: action formation and territories of knowledge. Res. Lang. Social Interact. 45, 1-29.

Heritage, John, 2012b. The epistemic engine: sequence organization and territories of knowledge. Res. Lang. Social Interact. 45, 30-52.

Heritage, John, Raymond, Geoffrey, 2005. The terms of agreement: indexing epistemic authority and subordination in talk-in-interaction. Social Psychol. Quart. 68, 15-38.

Hopper, Paul J., Thompson, Sandra A., 2008. Projectability and clause combining in interaction. In: Laury, Ritva (Ed.), Crosslinguistic Studies of Clause Combining. The Multifunctionality of Conjunctions. John Benjamins, Amsterdam, pp. 99-123.

Jefferson, Gail, 1988. On the sequential organization of troubles-talk in ordinary conversation. Social Probl. 35, 418-441.

Kärkkäinen, Elise, 2003. Epistemic Stance in English Conversation. A Description of Its Interactional Functions, with Focus on I think. Pragmatics \& Beyond New Series, vol. 115. John Benjamins, Amsterdam.

Kärkkäinen, Elise, 2007. The role of / guess in conversational stance taking. In: Englebretson, Robert (Ed.), Stancetaking in Discourse. Subjectivity, Evaluation, Interaction. Pragmatics \& Beyond New Series, vol. 164. John Benjamins, Amsterdam, pp. $183-219$.

Keevallik, Leelo, 2006. From discourse pattern to epistemic marker: Estonian (ei) tea 'don't know'. Nordic J. Linguist. 29, 173-200.

Keevallik, Leelo, 2011. The terms of not knowing. In: Stivers, Tanya, Mondada, Lorenza, Steensig, Jakob (Eds.), The Morality of Knowledge in Conversation. Studies in Interactional Sociolinguistics 29. Cambridge University Press, Cambridge, pp. 184-206.

Kielitoimiston sanakirja, 2012. Kotimaisten kielten keskuksen julkaisuja 166. Kotimaisten kielten keskus, Helsinki.

Koivisto, Aino, 2012. Discourse patterns for turn-final conjunctions. J. Pragmatics 44, 1254-1272.

Koivisto, Aino, 2014. Utterances ending in the conjunction että: complete or to be continued? In: Visapää, Laura, Kalliokoski, Jyrki, Sorva, Helena (Eds.), Contexts of Subordination. Cognitive, Interactional and Typological Perspectives. John Benjamins, Amsterdam, pp. $223-244$.

Koivisto, Aino, Laury, Ritva, Seppänen, Eeva-Leena, 2011. Syntactic and actional characteristics of Finnish että-clauses. In: Laury, Ritva, Suzuki, Ryoko (Eds.), Subordination in Conversation. Studies in Language and Social Interaction, vol. 24. John Benjamins, Amsterdam, pp. 69-102.

Langacker, Ronald, 2014. Subordination in a dynamic account of grammar. In: Visapää, Laura, Kalliokoski, Jyrki, Sorva, Helena (Eds.), Contexts of Subordination. Cognitive, Interactional and Typological Perspectives. John Benjamins, Amsterdam, pp. 17-72.

Laury, Ritva, 2012. Taking a stance and getting on with it: the form and function of the Finnish finite clausal extraposition construction. Text Talk 32 , 503-524.

Laury, Ritva, Seppänen, Eeva-Leena, 2008. Clause combining, interaction, evidentiality, participation structure, and the conjunction-particle continuum. The Finnish että In: Laury, Ritva (Ed.), Crosslinguistic Studies of Clause Combining. The Multifunctionality of Conjunctions. John Benjamins, Amsterdam, pp. 153-178.

Laury, Ritva, Suzuki, Ryoko (Eds.), 2011. Subordination in Conversation. A Cross-Linguistic Perspective Studies in Language and Social Interaction, vol. 24. John Benjamins, Amsterdam. 
Lee, Seung-Hee, 2013. Response design in conversation. In: Sidnell, Jack, Stivers, Tanya (Eds.), The Handbook of Conversation Analysis. Wiley-Blackwell, Chichester, pp. 415-432.

Local, John, 1992. Continuing and restarting. In: Auer, Peter, Di Luzio, Aldo (Eds.), The Contextualization of Language. John Benjamins, Amsterdam, pp. 273-296.

Mandelbaum, Jenny, 2013. Storytelling in conversation. In: Sidnell, Jack, Stivers, Tanya (Eds.), The Handbook of Conversation Analysis. WileyBlackwell, Chichester, pp. 492-507.

Mehan, Hugh, 1985. The structure of classroom discourse. In: van Dijk, Teuk A. (Ed.), Handbook of Discourse Analysis, vol. 3: Discourse and Dialogue. Academic Press, Orlando, pp. 119-131.

Niemi, Jarkko, 2013. Tiedon rajat ja vuorovaikutus. Toteamukseen tai vaihtoehtokysymykseen vastaavat vol oLLA-rakenteet.(English summary on the limits of knowledge. Responding to an assertion or a polar question with vol olLA'(it) may be' structures). Virittäjä 117, $201-241$.

Pomerantz, Anita, 1984a. Agreeing and disagreeing with assessments: some features of preferred/dispreferred turn shapes. In: Atkinson, J.M., Heritage, John (Eds.), Structures of Social Action. Cambridge University Press, Cambridge, pp. 57-101.

Pomerantz, Anita, 1984b. Giving a source or basis: the practice in conversation of telling 'how I know'. J. Pragmatics 8, 607-625.

Pomerantz, Anita, Heritage, John, 2013. Preference. In: Sidnell, Jack, Stivers, Tanya (Eds.), The Handbook of Conversation Analysis. WileyBlackwell, Chichester, pp. 210-228.

Rauniomaa, Mirka, 2007. Stance markers in spoken Finnish. Minun mielestä and minusta in assessments. In: Englebretson, Robert (Ed.), Stancetaking in Discourse: Subjectivity, Evaluation, Interaction. John Benjamins, Amsterdam, pp. 221-252.

Ruuskanen, Laura, 2007. Suomenoppija vastauspolulla-opetussyklin toteutuminen suomi toisena kielenä -oppitunnilla (Three-part instructional sequence in Finnish as a second language period). In: Tainio, Liisa (Ed.), Vuorovaikutusta luokkahuoneessa. Näkökulmana keskustelunanalyysi, Gaudeamus, Helsinki, pp. 90-116.

Sacks, Harvey, 1987 [1973]. On the preferences for agreement and contiguity in sequences in conversation. In: Button, Graham, Lee, John R.E. (Eds.), Talk and Social Organization. Multilingual Matters, Clevedon, pp. 54-69.

Sacks, Harvey, Schegloff, Emanuel A., Jefferson, Gail, 1974. A simplest systematics for the organization of turn-taking for conversation. Language 50, 696-735.

Schegloff, Emanuel A., 2007. Sequence organization in interaction. A primer in conversation analysis, vol. 1. Cambridge University Press, Cambridge.

Seppänen, Eeva-Leena, Herlin, Ilona, 2009. Kuvauksista seurauksiin: Kaksiulotteinen konstruktio niin A että (English summary From descriptions to effects: the two-dimensional construction niin A että 'so A that'). Virittäjä 113, 213-245.

Siro, Paavo, 1968. Suomen kielen että-lauseen ongelmasta (English summary On the problem of Finnish Clauses beginning with että 'that'). In: Fenno-Ugrica (Eds.), Juhlakirja Lauri Postin kuusikymmenvuotispäiväksi 17.3.1968. Suomalais-ugrilainen Seura, Helsinki, pp. $203-205$.

Stivers, Tanya, 2005. Modified repeats: one method for asserting primary rights from second position. Res. Lang. Social Interact. 38, 131-158

Stivers, Tanya, 2008. Stance, alignment, and affiliation during storytelling: when nodding is a token of affiliation. Res. Lang. Social Interact. 41 , 31-57.

Stivers, Tanya, 2013. Sequence organization. In: Sidnell, Jack, Stivers, Tanya (Eds.), The Handbook of Conversation Analysis. Wiley-Blackwell, Chichester, pp. 191-209.

Stivers, Tanya, Robinson, Jeffrey D., 2006. A preference for progressivity in interaction. Lang. Soc. 35, 367-392.

Stivers, Tanya, Rossano, Federico, 2010. Mobilizing response. Res. Lang. Social Interact. 43, 3-31.

Tainio, Liisa, 1998. Preferenssijäsennys (The preference organization). In: Tainio, Liisa (Ed.), Keskustelunanalyysin perusteet. Vastapaino Tampere, pp. 93-110.

Thompson, Sandra A., 2002. "Object complements" and conversation. Towards a realistic account. Stud. Lang. 26, $125-164$.

Vilkuna, Maria, 2000. Suomen lauseopin perusteet [The basics of Finnish syntax]. Kotimaisten kielten tutkimuskeskuksen julkaisuja 90. Edita, Helsinki.

Weatherall, Ann, 2011. I don't know as a prepositioned epistemic hedge. Res. Lang. Social Interact. 44, 317-337. 